Jaime Rodríguez Matos, Writing of the Formless:José Lezama Lima and the End of

Time. New York: Fordham University Press, 2017. ix + 232 pp. (Paper us\$25.00)

Writing of the Formless intervenes in recent debates in Latin Americanist theory through a painstaking engagement with, and radicalization of, the dominant forms of time that have defined Western hegemonic politics. Jaime Rodríguez Matos contends that successive temporal figures of politics-including narratives of Christianity, sovereignty, or nationhood as well as the supposedly oppositional stances of revolution, aesthetics, or nihilism — invariably establish the subject of politics as a predetermined function of ongoing power structures. Analyzing major texts and thinkers associated with these figures, he mines the poetic thought of Cuban writer José Lezama Lima as inspiration for imagining a writing that, in extracting itself from temporal form, would also be open to a total rethinking of politics. Such a writing of the formless "must be the time of a politicity that will only show itself as the radical reframing of what counts as politics in the first place" (p. 51).

Part 1 takes up various dimensions of the problem of political time; Part 2 is a series of seamless meditations on Lezama's interpretations of canonical intellectuals such as T.S. Eliot, Charles Baudelaire, and Paul Valéry. Throughout, Rodríguez Matos mixes exegeses of Lezama's poetry and essays with readings of aesthetic and political theory. Thus, although the book's structure is circuitously focused on Latin America (specifically, the context of the changing rhetoric of the Cuban Revolution and its persecution, and subsequent rehabilitation, of Lezama's own work), its principal hypotheses about form and time are explored in the realm of continental philosophy. As such, readers need an advanced level of familiarity not only with Lezama's notoriously opaque "poetic system" but also with a theoretical archive stretching from Aristotle to Alain Badiou.

Despite the occasional impression that its arguments use the Cuban context as a mere staging ground for meditations in political philosophy, the book offers stimulating material to adepts of Lezamian poetics and interlocutors of current polemics about the theorization of Latin American politics. Political emancipation is not, argues Rodríguez Matos, a matter of replacing one chronotope with another. Exchanging the "empty, homogeneous time" of modernity with the coevalness of democratization, or the sovereignty of the king with the sovereignty of the people, as the texts of the Cuban Revolution themselves reveal, only trades one form of temporal mastery for another: this is true even when radical discourses like the subaltern or the baroque are an exaltation of the formless. The task of critique is thus to read the ways

(C) JAIME HANNEKEN, 2018 | DOI:10.1163/22134360-09203032

This is an open access article distributed under the terms of the prevailing CC-BY-NC license 
traditional narratives of modernity or redemption and their counternarratives are together involved in an endless repetition, an exhaustion, of politics.

Chapter 1 gathers interpretations from Jacques Derrida, Catherine Malabou, and Badiou to argue for a radically deconstructive understanding of time; Chapter 2 dismantles the romantic gesture behind revolutionary constructions of sovereignty; Chapter 3 examines the coexistence of capitalist and communist time in early revolutionary texts; and Chapter 4 reads the antifoundationalism of nihilist discourse as a dialectical reversal and repetition of political foundations. The highlights of this rather dense set of studies come from the author's attention to Lezama and his work, both in an elucidating close reading of his poem "Aguja de diversos" and in the excavation of evolving critical approaches to his thought forged by the Origenista intellectuals Cintio Vitier and Fina García Marruz. In both cases, Lezama's understanding of the formless is used to issue incisive challenges to critics' longstanding focus on the poet's political significance; these readings expose with particular force the way contemporary scholarship's tendency to champion Lezama as a representative of alternative modernity and "counterconquest" is symptomatic of the reduction of neobaroque and Boom literature to a global product niche.

A final series of reflections delve into a more minute examination of Lezama's poetic system loosely organized around the rhetorical figure of aposiopesis, the interruption or pause in discourse that authorizes discourse's perpetuation. Thematizing such a pause in Lezamian poetics, Rodríguez Matos teases out the poet's articulation of the abyss as a potential orientation toward politics he characterizes, following Alberto Moreiras, as infrapolitical: an orientation that would neither attempt to cover over its lack of foundation nor hypostasize that lack into a new political grounding, but would assess its void as an opportunity to think politics differently. He sees that opportunity prefigured in Lezama's "writing of the formless": "a writing that wants to give testimony of the being of that absence, ... that does not foreclose the abyss in the name of a consistency that will redeem our world, a writing for which time ... cannot be offered as a clear synthetic image of any sort" (p. 128). Writing of the Formless refuses to shy away from, and at times even indulges in, the difficulty of Lezama's thought in order to showcase the formless nature of his writing: the result is a demanding, but ultimately rewarding read.

\section{Jaime Hanneken}

Department of Spanish and Portuguese Studies, University of Minnesota hanneo45@umn.edu 